\title{
MODEL TALKING STICK UNTUK MENINGKATKAN KETERAMPILAN SISWA DALAM PEMECAHANAN MASALAH
}

\author{
Ika Noviantiax, Riawan Yudi Purwoko ${ }^{\text {b }}$, Bambang Priyo Darminto ${ }^{c}$ \\ a,b,c Pendidikan Matematika/Universitas Muhammadiyah Purworejo, Jawa Tengah, 54111, Indonesia \\ ${ }^{\mathrm{x}}$ CorrespondingAuthor: E-mail addresses: ika.novianti66@gmail.com
}

\begin{abstract}
Penelitian ini bertujuan untuk menganalisis perbedaan kemampuan pemecahan masalah siswa dengan pembelajaran snowball throwing dengan talking stick antara kelompok self efficacy tinggi, sedang, dan rendah. Selain itu, peneliti juga menganalisis interaksi antara model pembelajaran terhadap kemampuan pemecahan. Penelitian ini dapat mengembangkan keterampilan siswa pada pemecahan masalah. Sampel penelitian ini adalah siswa kelas VII A dan VII B SMP, dengan metode pengumpulan data ialah angket, tes pemecahan masalah, dan dokumentasi. Analisis data yang digunakan yaitu analisis data awal dengan uji normalitas, uji homogenitas, dan uji keseimbangan. Uji hipotesis yang digunakan adalah ANAVA dua jalan sel tak sama. Berdasarkan tahapan penelitian di atas dapat disimpulkan bahwa (1) tidak ada perbedaan kemampuan pemecahan masalah siswa antara pembelajaran talking stick dengan snowball throwing, (2) ada perbedaan kemampuan pemecahan masalah antara kelompok self efficacy tinggi, sedang, dan rendah, (3) ada interaksi antara model pembelajaran dengan self efficacy siswa terhadap kemampuan pemecahan masalah.
\end{abstract}

Keywords: pembelajaran kooperatif, talking stick, snowball throwing, pemecahan masalah, self efficacy

\section{PENDAHULUAN}

Matematika merupakan ilmu dalam pendidikan yang dapat mengembangkan kemampuan penyelesaian masalah dalam kehidupan sehari-hari. Kemampuan yang dimiliki oleh seseorang merupakan bawaan sejak lahir atau merupakan hasil latihan sehari-hari. Salah satu kemampuan yang harus dimiliki siswa adalah kemampuan pemecahan masalah. Pemecahan masalah merupakan kemampuan yang penting bagi siswa. Pada proses pemecahan masalah terdapat faktor-faktor yang mendukung keberhasilan siswa dalam memecahkan masalah tersebut, antara lain: (1) konsentrasi, (2) sikap terhadap matematika, (3) motivasi untuk berprestasi, (3) harga diri, (4) keyakinan diri (Pimta dalam Ulya, 2016).

Penelitian sebelumnya telah dilakukan pada pemecahan masalah ditinjau dari self efficacy siswa namun dengan model pembelajaran yang berbeda (Ulya, R \& Hidayah, 2016). Dalam penelitian tersebut menghasilkan bahwa siswa dengan self efficacy tinggi memiliki kemampuan pemecahan masalah yang lebih baik dibandingkan siswa yang memiliki self efficacy sedang atau rendah. Penelitian lain meneliti kemampuan pemecahan masalah dengan pembelajaran talking stick (Maulidawati, 2014). Penelitian sebelumnya juga telah menunjukkan adanya hubungan self efficacy dengan kemampuan pemecahan masalah, dimana self efficacy mempengaruhi kinerja matematika dan proses pemecahan masalah (Butler, 2013). Subaidi (2016) meneliti mengenai self efficacy siswa dalam pemecahan masalah yang menunjukkan bahwa self efficacy merupakan faktor yang mempengaruhi proses pemecahan masalah. Untuk itu, perlu mempelajari hubungan antara self efficacy dengan kemampuan pemecahan masalah melalui suatu model pembelajaran tertentu.

Oleh karenanya, penelitian ini meneliti efek dari model pembelajaran kooperatif tipe talking stick dan snowball throwing terhadap kemampuan pemecahan masalah untuk memahami hubungan antara kemampuan pemecahan masalah dan self efficacy. Talking stick adalah model pembelajaran kooperatif belajar sambil bermain, dimana 
pembelajaran ini menggunakan tongkat sebagai alat bantu pembelajaran. Siswa yang mendapatkan tongkat maka akan mengerjakan soal di depan kelas atau menjawab pertanyaan dari guru. Talking stick mencakup 3 tahap terdiri dari (1) siswa belajar secara berkelompok, (2) siswa mendiskusikan materi dan tugas bersama kelompok, (3) siswa yang mendapat tongkat akan menjawab pertanyaan atau maju ke depan untuk mengerjakan.

\section{KAJIAN PUSTAKA}

Pembelajaran matematika adalah suatu aktivitas mental untuk memahami arti dan hubungan-hubungan serta simbol-simbol kemudian diterapkan pada situasi nyata (Fitri, 2014: 18). Ada beberapa model dalam pembelajaran, salah satunya adalah pembelajaran kooperatif. Menurut Slavin (dalam Hadianto, 2009: 83) menyatakan bahwa pembelajaran kooperatif merupakan pembelajaran oleh teman sebaya dimana siswa belajar dalam kelompok kecil yang memiliki kemampuan akademik yang berbeda-beda. Pembelajaran ini mengajarkan keterampilan-keterampilan khusus agar siswa dapat bekerja sama dengan baik dalam kelompoknya, menjadi pendengar yang baik, dan diberi lembar kegiatan berisi pertanyaan atau tugas untuk diajarkan (Hamdani, 2011: 31). Siswa akan memiliki rasa tanggung jawab karena mendapatkan tugas oleh guru yang harus dikerjakan oleh kelompoknya.

Pembelajaran kooperatif tipe talking stick memiliki tujuan untuk memperluas pengetahuan dan akurasi siswa dalam memahami konsep (Sari, D.M, 2017). Dengan menggunakan pembelajaran talking stick siswa dapat mempelajari matematika dan memahaminya dengan cara siswa sendiri karena siswa dapat berdiskusi dengan teman kelompok yang nantinya akan dibantu oleh guru. Menurut Widodo (dalam Paliensah, 2016) talking stick adalah suatu model pembelajaran yang menggunakan sebuah tongkat sebagai alat petunjuk giliran, siswa yang mendapat tongkat akan diberi pertanyaan dan harus menjawabnya, kemudian secara estafet tongkat tersebut berpindah ke tangan siswa yang lainnya.

Pada pembelajaran matematika manekankan pada pemecahan suatu masalah, dimana masalah dalam matematika biasanya disajikan dalam bentuk soal matematika. Suatu pertanyaan akan menjadi masalah jika seseorang tersebut tidak mempunyai aturan tertentu yang segera dapat dipergunakan untuk menemukan jawaban dari pertanyaan tersebut (Novferma, 2016: 77). Siswa harus berusaha optimal dalam menguasai konsep dan memecahkan masalah matematika dengan kebiasaan berpikir kritis, logis, sistematis, dan struktur.

Kemampuan pemecahan masalah matematika merupakan kecakapan atau potensi yang dimiliki seseorang atau siswa dalam menyelesaikan soal cerita, menyelesaikan soal yang tidak rutin, mengaplikasikan matematika dalam kehidupan sehari-hari atau keadaan lain, dan membuktikan, menciptakan atau menguji konjektur (Hadiansyah, 2016: 121). Pemecahan masalah matematika yang efektif memerlukan cara berpikir, memecahkan masalah matematika, cara belajar matematika, dan cara menghadapinya (Maree, 2016). Pada pembelajaran matematika, pemecahan masalah memiliki empat tahap (Polya dalam Wahyudi, 2012) yaitu memahami masalah, membuat rencana untuk menyelesaikan masalah, melaksanakan rencana yang dibuat pada langkah kedua, dan memeriksa ulang jawaban yang diperoleh.

Keyakinan matematika pada siswa bertahap berkembang sejak siswa mulai belajar matematika, dan memiliki pengaruh besar pada kegiatan pembelajaran matematika serta prestasi prestasi siswa (Jin et al. dalam Himmah, 2016). Siswa yang memiliki kepercayaan diri rendah di awal penelitian maka sikap siswa adalah psimis saat di hadapkan pada masalah matematika dan cepat menyerah sebelum mencobanya (Ramlan, 2016). Hal tersebut karena self efficacy 
merupakan keyakinan akan kemampuan yang dimiliki untuk berhasil dalam menyelesaikan sebuah tugas tertentu (Puspita, 2016: 557). Siswa cenderung menjalankan sesuatu apabila siswa merasa kompeten dan percaya diri (Noer, 2012). Semakin besar kepercayaan diri yang dimiliki maka kemungkinan berhasil dalam mengerjakan tugas juga akan semakin besar. Oleh karena itu pentingnya self efficacy dalam meningkatkan kemampuan siswa pada pemecahan masalah sejalan dengan penelitian sebelumnya yang menyatakan bahwa self efficacy dalam matematika dapat mempengaruhi proses pemecahan masalah (Butler, 2013).

\section{METODOLOGI}

\section{a. Populasi dan Sampel}

Populasi penelitian ini adalah seluruh siswa kelas VII yang terdiri dari kelas VII A sampai dengan VII F. pengambilan sampel menggunakan teknik random sampling. Sehingga diperoleh sampel yaitu siswa kelas VII A sebanyak 32 siswa dan VII B sebanyak 32 siswa.

b. Desain Penelitian

Penelitian ini merupakan

penelitian kuantitatif dengan bentuk desain penelitian adalah quasi eksperimen. Kelas eksperimen I menggunakan model snowball throwing dan kelas eksperimen II menggunakan model telking stick. Teknik pengumpulan data menggunakan angket, tes pemecahan masalah, dan dokumentasi. Angket digunakan untuk mengukur self efficacy pada siswa.

\section{c. Alur Pengolahan Data}

Pada pengolahan data penelitian ini menggunakan analisis data awal dan analisis data akhir. Analisis data awal menggunakan uji normalitas, uji homogenitas, dan uji keseimbangan. Untuk analisis data akhir menggunakan uji normalitas, uji homogenitas, dan uji hipotesis. Uji hipotesis dalam penelitian ini adalah uji ANAVA dua jalan sel tak sama, dan uji lanjut pasca ANAVA menggunakan uji Scheffe.

\section{HASIL DAN PEMBAHASAN}

a. Deskripsi data

Peneliti mengambil data menggunakan angket untuk dapat mengetahui self efficacy siswa yang kemudian dikelompokkan menjadi tiga kategori. Kelompok self efficacy tersebut yaitu tinggi, sedang dan rendah. Pada kelas eksperimen I dan ekperimen II jumlah anak yang memiliki self efficacy tinggi masing-masing 7 siswa dan 8 siswa. Kategori self efficacy sedang untuk kelas eksperimen I sebanyak 18 siswa dan kelas eksperimen II sebanyak 18 siswa, sedangkan pada kategori rendah untuk kelas eksperimen I sebanyak 7 siswa dan kelas eksperimen II sebanyak 6 siswa.

Peneliti mengambil data tes pemecahan masalah dengan mengujikan soal (tes) pada kedua kelas yang dikenai model pembelajaran. Berdasarkan hasil tes pemecahan masalah yang telah dilakukan diperoleh data hasil tes pemecahan masalah siswa kelompok talking stick dari 32 siswa kelompok talking stick diperoleh nilai rata-rata kelompok adalah 91,667, nilai tertinggi 100, nilai terendah 77,083. Sementara data hasil pemecahan masalah siswa kelompok snowball throwing dari 32 siswa kelompok snowball throwing diperoleh nilai rata-rata kelompok adalah 90,6898, nilai tertinggi 100, nilai terrendah 62,25.

\section{b. Analisis Data}

Analisis data awal yang digunakan adalah uji normalitas, uji homogenitas, dan uji keseimbangan. Hasil dari uji normalitas menunjukkan $L_{\text {ktung }} \notin D K$ yang artinya bahwa kemampuan pemecahan masalah siswa kelompok talking stick dan snowball throwing berasal dari populasi yang berdistribusi normal. Dimana Lobs untuk kelas talking stick adalah 0,090, dan $\mathrm{L}_{\text {obs }}$ kelas snowball throwing sebesar 0,101. Selanjutnya dilakukan uji homogenitas data awal 
dengan hasil $\mathrm{F}_{\text {obs }}$ sebesar 1,2334 dengan Ftabel $=1,8221$. Hal ini menunjukkan $F_{\text {obs }} \notin D K$ maka sampel kelompok talking stick dan snowball throwing sebelum perlakuan mempunyai variansi yang sama. Selanjutnya dilakukan uji kesimbangan, menunjukkan bahwa tobs sebesar 0,396 dan $t_{\text {tabel }}=1,998$. Nilai $t_{\text {obs }} \notin D K$ maka kelompok talking stick dan snowball throwing dalam keadaan seimbang.

Analisis data akhir menggunakan uji ANAVA dua jalan sel tak sama. Pada pengujian ini diperoleh data sebagai berikut:

Tabel 1. Uji Hipotesis ANAVA

\begin{tabular}{lcccl}
\hline Sumber & DK & $\mathrm{F}_{\text {obs }}$ & Fa & $\begin{array}{l}\text { Keputus } \\
\text { an }\end{array}$ \\
\hline Model (A) & 1 & 0,33 & 4,0 & $\begin{array}{l}\mathrm{H}_{0} \\
\text { diterima }\end{array}$ \\
Self efficacy & 2 & 33,5 & 3,1 & $\mathrm{H}_{0}$ \\
(B) & & 4 & 6 & ditolak \\
Interaksi & 2 & 3,46 & 3,1 & $\mathrm{H}_{0}$ \\
(AB) & & & 6 & ditolak \\
\hline
\end{tabular}

Dari perhitungan ANAVA menunjukkan $\mathrm{H}_{0 \mathrm{~A}}$ diterima, artinya bahwa tidak ada perbedaan pemecahan masalah matematika antara model kooperatif snowball throwing $\left(\mathrm{A}_{1}\right)$ dan talking stick $\left(\mathrm{A}_{2}\right)$. Hasil lainnya menunjukkan bahwa $\mathrm{H}_{0 \mathrm{~B}}$ ditolak, artinya ada perbedaan kemampuan pemecahan masalah antara siswa yang memiliki self efficacy tinggi $\left(\mathrm{B}_{1}\right)$, self efficacy sedang $\left(\mathrm{B}_{2}\right)$, dan self efficacy rendah $\left(\mathrm{B}_{3}\right)$. Perhitungan selanjutnya menunjukkan $\mathrm{H}_{0 \mathrm{AB}}$ ditolak yang berarti bahwa ada interaksi efek dari model pembelajaran (A) dan self efficacy (B). Perhitungan selanjutnya yaitu menggunakan uji Scheffe untuk mengetahui perbedaan antara self efficacy tinggi, sedang, dan rendah. Hasil tersebut disajikan dalam tabel berikut.

Tabel 2. Perhitungan Scheffe antara Efek Pembelajaran dengan Self efficacy

\begin{tabular}{|c|c|c|c|}
\hline $\begin{array}{l}\text { Komparas } \\
\text { i }\end{array}$ & $F_{\text {obs }}$ & $\mathrm{F}_{0.05 ; 2 ; 58}$ & $\begin{array}{l}\text { Keputusa } \\
\mathrm{n}\end{array}$ \\
\hline $\mathrm{B}_{1}$ vs $B_{2}$ & $\begin{array}{l}25,61 \\
1\end{array}$ & 6,32 & $\begin{array}{l}\mathrm{H}_{01} \\
\text { ditolak }\end{array}$ \\
\hline $\mathrm{B}_{1} \mathrm{vs} \mathrm{B}_{3}$ & 53,33 & 6,32 & $\begin{array}{l}\mathrm{H}_{02} \\
\text { ditolak }\end{array}$ \\
\hline
\end{tabular}

\begin{tabular}{llll}
\hline $\mathrm{B}_{2} \mathrm{vs} \mathrm{B}_{3}$ & 14,03 & 6,32 & $\begin{array}{l}\mathrm{H}_{03} \\
\text { ditolak }\end{array}$ \\
\hline
\end{tabular}

$\mathrm{H}_{01}$ ditolak artinya ada perbedaan kemampuan pemecahan masalah antara siswa dengan self efficacy tinggi dan self efficacy sedang. Keputusan $\mathrm{H}_{02}$ ditolak yang artinya ada perbedaan kemampuan pemecahan masalah antara self efficacy tinggi dengan self efficacy rendah. Hasil selanjutnya $\mathrm{H}_{03}$ ditolak, menunjukkan bahwa ada perbedaan kemampuan pemecahan masalah antara siswa yang memiliki self efficacy sedang dengan siswa yang memiliki self efficacy rendah.

Berdasarkan hasil uji Scheffe terhadap kemampuan pemecahan masalah ditinjau dari self efficacy siswa diperoleh sebagai berikut:

a. Kemampuan pemecahan masalah siswa dengan self efficacy tinggi lebih baik daripada kemampuan pemecahan masalah matematika dengan self efficacy sedang.

b. Kemampuan pemecahan masalah matematika siswa dengan self efficacy tinggi lebih baik daripada kemampuan pemecahan masalah matematika dengan self efficacy rendah.

c. Kemampuan pemecahan masalah siswa dengan self efficacy sedang lebih baik daripada kemampuan pemecahan masalah dengan self efficacy rendah.

Pelaksanaan model pembelajaran talking stick menjadikan siswa lebih aktif untuk mengerjakan di depan kelas saat proses pembelajaran berlangsung. Siswa menjadi lebih rajin dan semangat dalam mengerjakan tugas-tugasnya karena guru akan memberikan tongkat ke beberapa siswa untuk maju ke depan mengerjakan soal tersebut. Hal itu membantu siswa dalam belajar dan membangun kepercayaan diri siswa untuk mengerjakan di depan kelas serta membantu siswa untuk mengingat materi pembelajaran karena siswa terlibat langsung dalam proses pembelajaran.

Berdasarkan hasil uji komparasi ganda antar kolom dapat disimpulkan bahwa kemampuan pemecahan masalah kelompok siswa dengan self efficacy tinggi 
lebih baik dari kemampuan pemecahan masalah kelompok self efficacy yang sedang atau rendah. Hal ini sesuai dengan penelitian Ulya (2016) bahwa siswa yang memiliki self efficacy tinggi mampu memahami masalah, merencanakan pemecahan masalah, melaksanakan rencana, serta memeriksa kembali dengan benar dan lengkap. Siswa tersebut juga cenderung lebih semangat belajar untuk mencapai tujuan yang diharapkan jika dibandingkan dengan siswa yang memiliki self efficacy sedang maupun rendah.

Siswa dengan self efficacy sedang akan dapat mengikuti kegiatan pembelajaran lebih baik dari siswa yang memiliki self efficacy rendah. Hal ini dikarenakan siswa yang memiliki self efficacy sedang memiliki semangat dan keyakinan untuk mengerjakan soal di depan kelas. Sedangkan siswa yang memiliki self efficacy rendah cenderung tidak tertarik untuk mengerjakan soal di depan dan terkadang mengikuti jawaban dari teman yang sudah mengerjakan di depan kelas selama proses pembelajaran. Hal ini didukung oleh pernyataan bahwa siswa yang memiliki kepercayaan diri yang rendah maka sikap siswa adalah psimis saat dihadapkan pada masalah matematika dan cepat menyerah sebelum mencobanya (Ramlan, 2016).

Berdasarkan catatan lapangan yang diperoleh peneliti, pada kelas talking stick siswa dengan self efficacy tinggi berani untuk mengerjakan di depan kelas. Dalam pengerjaan soal tes pemecahan masalah siswa dengan self efficacy tinggi cenderung mengerjakan langsung jawaban tanpa menuliskan apa yang diketahui, ditanyakan, dan proses pengerjaan ditulis pada kertas buram. Siswa dengan self efficacy rendah mayoritas malu jika mengerjakan di depan. Saat mengerjakan soal tes pemecahan masalah siswa tersebut menuliskan apa yang diketahui, ditanyakan, jawab dan kesimpulannya. Hasil dari tes pemecahan masalah pada kelas ini banyak siswa yang tidak menuliskan langkah-langkahnya, karena siswa membuat rencana dan prosesnya pada kertas buram.

Model pembelajaran talking stick mengakibatkan terjadinya interaksi antar siswa melalui diskusi sehingga memungkinkan siswa lebih mudah dalam memahami materi pembelajaran, dan membuat siswa aktif untuk mengerjakan di depan kelas. Hal ini akan berdampak pada kepercayaan diri siswa sehingga siswa akan lebih mudah dalam memecahkan masalah karena siswa telah belajar materi terlebih dahulu sebelum pembelajaran dimulai.

Berikut disajikan salah satu jawaban dari soal tes pemecahan masalah siswa yang dikenai model pembelajaran talking stick. Setiap jawaban akan dikaitkan dengan indikator yang ada pada pemecahan masalah. Dalam setiap indikator, peneliti memberikan skor 3 jika siswa menjawab dengan benar dan sesuai dengan konsep yang dipelajari.

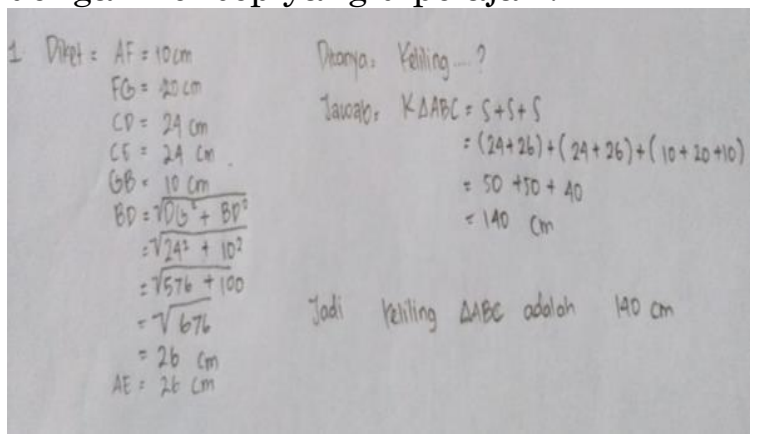

Gambar 1. Jawaban soal nomor 1 tes pemecahan masalah kelas talking stick Berdasarkan pedoman penskoran, jawaban pada Gambar 1 siswa mendapat skor 3 disetiap indikator karena siswa mengerjakan soal menggunakan konsep yang dipelajari dan jawaban benar.

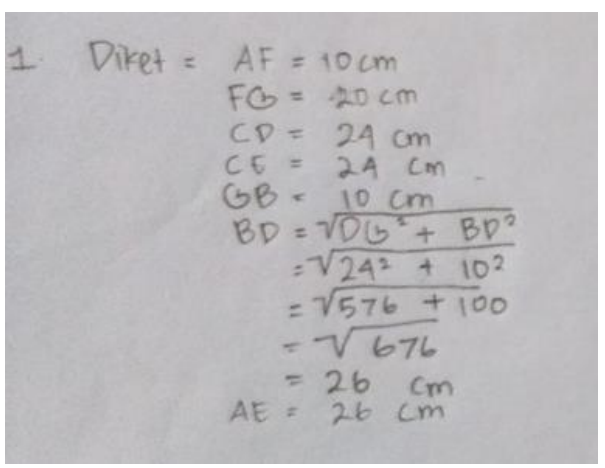

Gambar 1.1 Siswa mampu menulis apa yang diketahui dari soal yang merupakan 
indikator 1 dalam pemecahan masalah yaitu memahami masalah.

$$
\text { Ditanya : Keliling ...? }
$$

Gambar 1.2 siswa mampu menuliskan apa yang ditanyakan dari soal, merupakan bentuk indikator 2 dalam pemecahan masalah yaitu membuat rencana untuk menyelesaikan masalah.

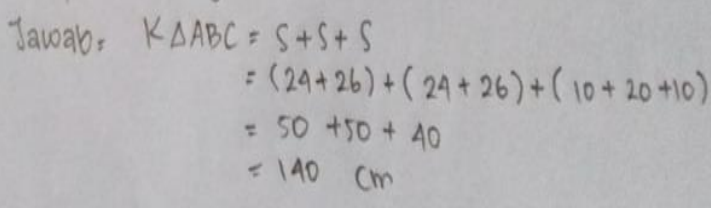

Gambar 1.3 Siswa mampu menerapkan indikator pemecahan masalah ke 3 yaitu melaksanakan rencana yang dibuat pada langkah kedua.

\section{Jadi reliling $\triangle A B C$ adalah $140 \mathrm{~cm}$}

Gambar 1.4 Siswa mampu menerapkan indikator pemecahan masalah ke 4 yaitu memeriksa kembali dan yakin bahwa jawaban pada langkah ketiga sudah tepat.

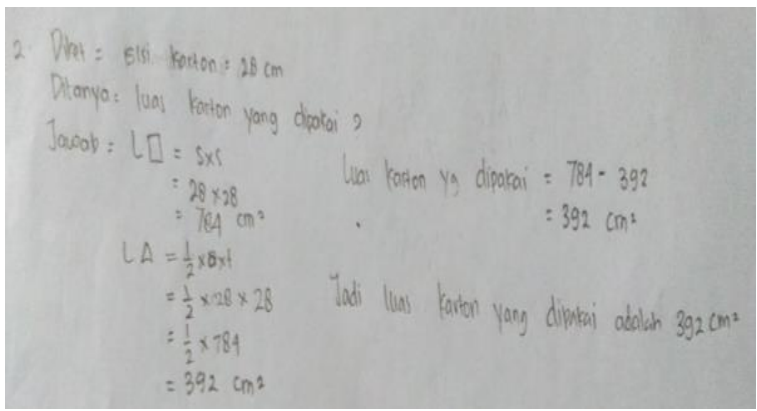

Gambar 2. Jawaban soal nomor 2 tes pemecahan masalah kelas talking stick Pada Gambar 2 siswa mendapat skor 3 disetiap indikator karena siswa mengerjakan soal menggunakan konsep yang dipelajari dan jwaban benar. Siswa mampu memahami masalah, membuat rencana penyelesaian, melaksanakan rencana penyelesaian yang dibuat pada langkah 2, memeriksa ulang jawaban yang diperoleh.

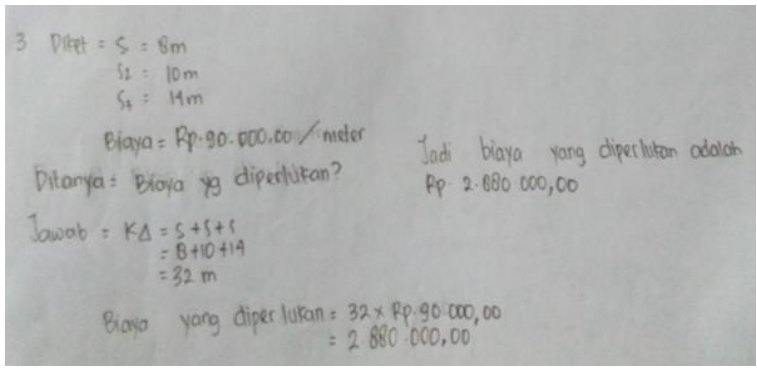

Gambar 3. Jawaban soal nomor 3 tes pemecahan masalah kelas talking stick

Berdasarkan pedoman penskoran, jawaban pada Gambar 3 siswa mendapat skor 3 disetiap indikator karena siswa mengerjakan soal menggunakan konsep yang dipelajari dan jwaban benar. Siswa mampu memahami masalah, membuat rencana penyelesaian, melaksanakan rencana penyelesaian yang dibuat pada langkah 2, dan memeriksa ulang jawaban yang diperoleh.

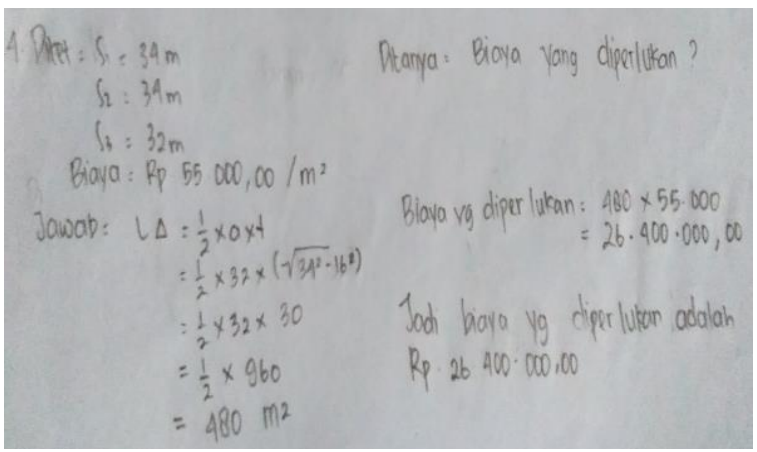

Gambar 4. Jawaban soal nomor 4 tes pemecahan masalah kelas talking stick Pada Gambar 4 sesuai dengan pedoman penskoran siswa mendapat skor 3 disetiap indikator karena siswa mengerjakan soal menggunakan konsep yang dipelajari dan jwaban benar. Siswa mampu memahami masalah, membuat rencana penyelesaian, melaksanakan rencana penyelesaian yang dibuat pada langkah 2, memeriksa ulang jawaban yang diperoleh. 


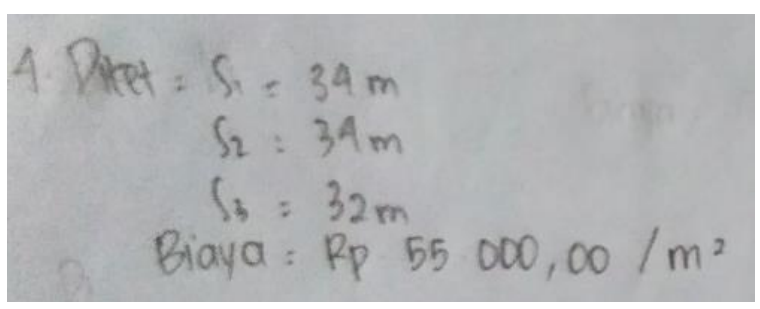

Gambar 4.1 Siswa mampu menulis apa yang diketahui dari soal yang merupakan indikator 1 dalam pemecahan masalah yaitu memahami masalah.

\section{Ditarya: Biaya vang diperlukan?}

Gambar 4.2 siswa mampu menuliskan apa yang ditanyakan dari soal, merupakan bentuk indikator 2 dalam pemecahan masalah yaitu membuat rencana untuk menyelesaikan masalah.

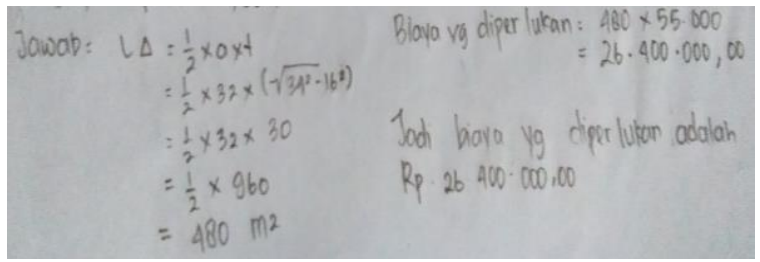

Gambar 4.3 Siswa mampu menerapkan indikator pemecahan masalah ke 3 yaitu melaksanakan rencana yang dibuat pada langkah kedua. Kemudian siswa mampu menerapkan indikator pemecahan masalah ke 4 yaitu memeriksa kembali dan yakin bahwa jawaban pada langkah ketiga sudah tepat.

Dilihat dari hasil penelitian di lapangan, pembelajaran talking stick dan snowball throwing sama-sama melatih kemampuan siswa dalam mengerjakan soal-soal yang diberikan oleh guru dan menumbuhkan kepercayaan diri pada siswa lewat game yang ditimbulkan pada kedua kelompok pembelajaran. Mengajak siswa untuk aktif dalam proses pembelajaran sehingga berpengaruh pada self efficacy pada siswa, dalam hal ini siswa lebih yakin dalam melakukan pemecahan masalah. Berdasarkan uraian tersebut, menunjukkan bahwa ada interaksi antara model pembelajaran dengan self efficacy siswa terhadap kemampuan pemecahan masalah.

\section{KESIMPULAN DAN SARAN}

a. Kesimpulan

Tidak ada perbedaan kemampuan pemecahan masalah siswa yang diberi perlakuan model pembelajaran kooperatif tipe talking stick dengan snowball throwing. Ada perbedaan kemampuan pemecahan masalah antara kelompok self efficacy tinggi, sedang, dan rendah. Berdasarkan perbedaan tersebut diperoleh kemampuan pemecahan masalah siswa dengan self efficacy tinggi lebih baik daripada kemampuan pemecahan masalah matematika dengan self efficacy sedang. Kemampuan pemecahan masalah matematika siswa dengan self efficacy tinggi lebih baik daripada kemampuan pemecahan masalah matematika dengan self efficacy rendah. Kemampuan pemecahan masalah siswa dengan self efficacy sedang lebih baik daripada kemampuan pemecahan masalah dengan self efficacy rendah. Ada interaksi antara model pembelajaran dengan self efficacy siswa terhadap kemampuan pemecahan masalah.

b. Saran

Peneliti berharap penelitian ini bisa menjadi masukan kepada pihak guru dan sekolah. Kepada guru atau calon guru, hendaknya menggunakan model atau strategi yang tepat dalam pembelajaran untuk menyampaikan materi pelajaran, memilih pembelajaran yang menyenangkan bagi siswa namun juga bisa mengembangkan potensi yang dimiliki siswa. Kepada peneliti selanjutnya, dapat melakukan penelitian dengan meninjau permasalahan lain agar dapat mengetahui faktor yang mempengaruhi kemampuan siswa khususnya pada pelajaran matematika.

\section{ACKNOWLEDGMENTS}

Tingkat self-efficacy siswa perlu
dikembangkan dalam pemecahan masalah 
matematika untuk mencapai hasil belajar yang maksimal. Oleh karena itu, penting bagi seorang guru untuk mengembangkan self-efficacy untuk setiap siswa dengan cara atau metode yang berbeda. Penelitian selanjutnya diharapkan tidak hanya menyelidiki pendekatan lain untuk meningkatkan self-efficacy siswa dalam matematika. tetapi juga harus fokus pada efek yang lebih besar untuk menyempurnakan hasil penelitian ini.

\section{DAFTAR PUSTAKA}

Butler, A. G. 2013. Exploring the Role of Social Reasoning and Self-Efficacy in the Mathematics Problem solving Performance of Lower- and HigherIncome Children. Bryant University Journal of Educational Research and Practice 2013. DOI: 10.5590/JERAP.2013.03.1.07.

Volume 3, Issue 1, Pages 93-119.

Fitri, R. 2014. Penerapan Strategi The Firing Line pada Pembelajaran Matematika Siswa Kelas XI IPS SMA Negeri 1 Batipuh. Jurnal Pendidikan Matematika. Vol. 3 No. 1. Part 2 Hal 18-22.

Hadiansyah, D. \& dkk. 2016. Perbandingan Kemampuan Proses Pemecahan Masalah Matematis antara Implementasi Strategi Konflik Kognitif dengan Model Pembelajaran Discovery Learning. Program Studi Pendidikan Matematika STKIP Garut. Jurnal Riset Pendidikan. ISSN: 2460-1470. Vol. 2, No. 2, November 2016.

Hadianto, U. 2009. Efektivitas Pembelajaran Kooperatif dengan Group Investigation terhadap Prestasi Belajar Matematika Ditinjau dari Motivasi Berprestasi. Tesis. Pendidikan Matematika Universitas Sebelas Maret Surakarta.

Hamdani. 2011. Strategi Belajar Mengajar. Bandung: CV Pustaka Setia.

Himmah, W. Izzatul. 2016. Analisis Belief Matematik Siswa Tingkat SMP.
Journal of Medives. Journal of Mathematics Education IKIP Veteran Semarang. e-ISSN: 25495070 p-ISSN: 2549-8231. MEDIVES 1 (1) (2017) 49-58

Maree, K. 2016. Problem Solving in Mathematics. Universitiet Van Pretoria.

Noer, S. H. 2012. Self-efficacy Mahasiswa Terhadap Matematika. Prosiding Pendidikan Matematika FMIPA UNY. ISBN : 978-979-16353-8-7.

Novferma, N. 2016. Analisis Kesulitan dan Self-Efficacy Siswa SMP dalam Pemecahan Masalah Matematika Berbentuk Soal Cerita. Jurnal Riset Pendidikan Matematika. Volume 3 Nomor 1, Mei 2016, (76 - 87) http://journal.uny.ac.id.

Paliensah, A. 2016. Penerapan Model Talking stick pada Pembelajaran Matematika Siswa Kelas VII SMP Negeri 6 Lubuklinggau Tahun Pelajaran 2016/2017. Artikel Ilmiah STKIP Lubuklinggau.

Puspita, W. R. 2016. Upaya Meningkatkan Self-efficacy Melalui Model Learning Cycle $5 E$ pada Pokok Bahasan Perbandingan. Seminar Nasional Matematika dan Pendidikan Matematika UNY 2016.

Ramlan, A.M. 2016. The Effect of Van Hiele Learning Model Toward Geometric Reasoning, Ability Based on Self-efficacy of Senior High School Students. Journal of Mathematics Education. ISSN: 2528-2468.Vol 1, No 2, July 2016.

Sari, D.M. 2017. Analysis of Student's Mathematical Communication Ability by Using Cooperative Learning Talking stick Type. Journal of Mthematics Education. DOI 10.22460/infinity. v6i2.p183194. 
Subaidi, A. 2016. Self-efficacy Siswa dalam Pemecahan Masalah Matematika. Jurnal Program Studi Pendidikan Matematika Universitas Madura.

Sugiyono. 2015. Metode Penelitan Kuantitatif, Kualitatif, dan R\&D. Bandung: Alfabeta.

Ulya, R. \& I. Hidayah. 2016. Kemampuan Pemecahan Masalah Ditinjau dari Self-efficacy Siswa dalam Model Pembelajaran Missouri Mathematics Project. Unnes Journal of Mathematics Education Research. pISSN 2252-6455. e-ISSN 2502-4507.

Wahyudi, \& I. Budiono. 2012. Pemecahan Masalah Matematika. Diakses dari http://repository.uksw.edu /bitstream/1234567/2476/21/book/Wa hyudi-Inawati/Pemecahan-masalahmatematika/Unit9.pdf. 
84 EduMa Vol. 8 No. 1 Juli 2019

ISSN 2086 - 3918 